\title{
Organic acids in the rhizosphere and phytoavailability of sewage sludge-borne trace elements
}

\author{
Adriana Marlene Moreno Pires( ${ }^{(1)}$, Giuliano Marchi(2), Maria Emília Mattiazzo ${ }^{(3)}$ \\ and Luiz Roberto Guimarães Guilherme ${ }^{(4)}$
}

\begin{abstract}
(1)Embrapa Meio Ambiente, Caixa Postal 69, CEP 13820-000 Jaguariúna, Brazil, SP. E-mail: adriana@cnpma.embrapa.br (2)Embrapa Cerrados, Caixa Postal 8223, CEP 73310-970 Planaltina, Brazil, DF. E-mail: giuliano.marchi@cpac.embrapa.br (3)Escola Superior de Agricultura Luiz de Queiroz, Dep. de Química, Caixa Postal 09, CEP 13418-900 Piracicaba, Brazil, SP. E-mail: mariaemilia@biossolidos.com.br (4)Universidade Federal de Lavras, Dep. de Ciência do Solo, Caixa Postal 37, CEP 37200-000 Lavras, Brazil, MG. E-mail: guilherm@ufla.br
\end{abstract}

\begin{abstract}
The aim of this work was to quantify low molecular weight organic acids in the rhizosphere of plants grown in a sewage sludge-treated media, and to assess the correlation between the release of the acids and the concentrations of trace-elements in the shoots of the plants. The species utilized in the experiment were cultivated in sand and sewage sludge-treated sand. The acetic, citric, lactic, and oxalic acids, were identified and quantified by high performance liquid chromatography in samples collected from a hydroponics system. Averages obtained from each treatment, concentration of trace elements in shoots and concentration of organic acids in the rhizosphere, were compared by Tukey test, at 5\% of probability. Linear correlation analysis was applied to verify an association between the concentrations of organic acids and of trace elements. The average composition of organic acids for all plants was: 43.2, 31.1, 20.4 and 5.3\% for acetic, citric, lactic, and oxalic acids, respectively. All organic acids evaluated, except for the citric acid, showed a close statistical agreement with the concentrations of $\mathrm{Cd}, \mathrm{Cu}, \mathrm{Ni}$, and $\mathrm{Zn}$ found in the shoots. There is a positive relationship between organic acids present in the rhizosphere and trace element phytoavailability.
\end{abstract}

Index terms: biosolid, exudates, heavy metals, availability.

\section{Ácidos orgânicos na rizosfera e fitodisponibilidade de elementos-traço originários de lodo de esgoto}

\begin{abstract}
Resumo - O objetivo deste estudo foi quantificar ácidos orgânicos de baixo peso molecular presentes na rizosfera de plantas cultivadas na presença de lodo de esgoto e avaliar a correlação entre a liberação dos ácidos e a concentração de elementos-traço nas plantas. As espécies utilizadas no experimento foram cultivadas em areia e areia com lodo de esgoto. Os ácidos acético, cítrico, lático e oxálico foram identificados e quantificados por cromatografia líquida de alta eficiência em amostras coletadas de um sistema hidropônico. As médias obtidas em cada tratamento, para concentração de elementos-traço na parte aérea e para concentração de ácidos orgânicos rizosféricos, foram comparadas pelo teste de Tukey, a 5\% de probabilidade. A análise de correlação linear foi utilizada para verificar a associação entre as concentrações de ácidos orgânicos e elementos-traço. A média de composição dos ácidos orgânicos para todas as plantas foi 43,2, 31,1,20,4 e 5,3\%, para os ácidos acético, cítrico, lático e oxálico, respectivamente. Todos os ácidos orgânicos, com exceção do cítrico, correlacionaram-se com as concentrações de $\mathrm{Cd}, \mathrm{Cr}, \mathrm{Cu}, \mathrm{Ni}$ e $\mathrm{Zn}$ na parte aérea das plantas. Existe associação entre ácidos orgânicos rizosféricos e fitodisponibilidade de elementos-traço.
\end{abstract}

Termos para indexação: biossólido, exsudatos, metais pesados, disponibilidade.

\section{Introduction}

The presence of trace elements in sewage sludge is one of the limitations imposed on its addition to soils. The agricultural use of biologically-treated sewage sludge regulation in São Paulo State, Brazil (Cetesb, 1999), limits the maximum concentration of trace elements, as well as the annual and accumulated load rates allowed to be added to soils. This regulation presents the same limits imposed by the United States (Estados Unidos, 1993), which were calculated from risk evaluations (National Research Council, 1983) based on possible routes that trace elements could follow after they had been added to soils. In spite of the risk evaluation studies, several 
authors, among them McBride (1995), criticized the adopted rules, mainly with regard to the phytoavailability issue.

Total concentrations of trace elements also may not be a valid argument to limit sewage sludge loads to agricultural fields. Most of the trace elements present in sewage sludge is found to be specifically adsorbed by mineral particles and organic matter from the residue, tending to remain unavailable to plants after they had been added to the soil (Candelaria, 1995; Bertoncini, 2002). Therefore, less than $1 \%$ of the total amount of trace elements present in biosolids is absorbed by plants (Chang et al., 1997).

The trace element availability is closely related to the solubilization processes that occur in the soil. Once plants take up only those elements that are available to them in the soil solution, the equilibrium between solution and solid phase, as well as its reaction kinetics, should be considered when the trace elements phytoavailability is predicted (Sposito, 1981). Considering that trace elements generally are present in soil solution at low concentrations, disturbances of solution:solid phase equilibrium would show influence on trace elements phytoavailability (Koo, 2001). Therefore, trace element mobilization from solid phase due to the formation of soluble complexes could play an important role on their phytoavailability.

Organic ligands present in the rhizosphere, such as low molecular weight organic acids and amino acids, are considered solubilization agents of metals linked to some mineral fractions of soils, because they form stable soluble complexes with metallic ions (Marschner, 1995; Chen et al., 2003; Qin et al., 2004). Mench \& Martin (1991) observed that $\mathrm{Cd}, \mathrm{Cu}, \mathrm{Fe}, \mathrm{Mn}, \mathrm{Ni}$ and $\mathrm{Zn}$ present in the soil were solubilized by root exudates released by different plants. Krishnamurti et al. (1997) concluded that soil Cd is mobilized by acetic, citric, oxalic, fumaric and succinic acids, which are normally found in the rhizosphere. Koo (2001) assessed the $\mathrm{Cd}, \mathrm{Cr}, \mathrm{Cu}, \mathrm{Ni}$, $\mathrm{Pb}$ and $\mathrm{Zn}$ solubilization kinetics in soils treated with sewage sludge, in the presence of organic acids and their phytoabsorption. The results obtained showed similarity in the performance of the solubilization and phytoabsorption processes.

There is not a consensus about organic acids composition in the rhizhosphere. Citric acid is considered to be the most abundant (Gardner et al., 1983; Li et al., 1997). Lauherte et al. (1990) determined the presence of citric, malic, fumaric, gluconic, lactic and succinic acids in the rhizosphere of different species. Studying the corn rhizosphere, Mench et al. (1988) found the following concentration sequence: succinic $>$ citric $>$ lactic $>$ malic. Koo (2001) studied the rizhosphere of different species and observed that acetic, butiric, lactic and oxalic acids together represented 72 to $88 \%$ of the low molecular weight organic acids collected.

For these reasons, the study of organic acids composition in the rhizosphere of several plant species and of the connection between these organic acids and trace elements uptaken by plants is of great interest and may represent a step forward concerning the phytoavailability issue.

The objective of this work was to the identify and quantify the organic acids composition in the rhizosphere of four plant species grown in sewage sludge-treated media and to evaluate the relationship between the concentration of low molecular weight organic acids in the rhizosphere and the concentration of trace elements in the shoots of those plants.

\section{Material and Methods}

Four plant species, marandu grass (Brachiaria brizantha L.), eucalyptus (a hybrid of Eucalyptus grandis L. and E. urophyla L.), sugarcane (Saccharum officinarum L., var. IAC-87.3396), and corn (Zea mays L., var. Traktor) were grown in $5 \mathrm{~kg}$ pots containing sand or sewage sludge-treated sand. The hydroponics system consisted of four pots connected to a $50 \mathrm{~L}$ container filled with aerated nutrient solution. The solution was pumped to the pots at intervals of two hours.

The sewage sludge used was produced by the anaerobic digestion method of activated sewage sludge at the wastewater treatment plant of Barueri city in São Paulo, Brazil (Table 1).

The experiment was installed in a completely randomized design, with four replicates and ten treatments: sand only; sewage sludge-treated sand only; marandu grass grown in sand; marandu grass grown in sewage sludge-treated sand; sugarcane grown in sand; sugarcane grown in sewage sludge-treated sand; eucalyptus grown in sand; eucalyptus grown in sewage sludge-treated sand; corn grown in sand, and corn grown in sewage sludge-treated sand.

Pots containing sand $(3 \mathrm{~kg})$ and sand $(3 \mathrm{~kg})$ mixed to sewage sludge ( $80 \mathrm{Mg} \mathrm{ha}^{-1}$ ) were incubated for 30 days. After that, thirty seeds of marandu grass, two sugarcane setts, two eucalyptus seedlings or six corn seeds were sown per planted pot. The nutrient solution ( $\mathrm{pH} \mathrm{6.0)} \mathrm{was}$ 
composed of (mmol L-1 $): \mathrm{Ca}\left(\mathrm{NO}_{3}\right)_{2}, 2.0 ; \mathrm{KCl}, 1.0 ; \mathrm{NaCl}$, $0.1 ; \mathrm{MgSO}_{4}, 0.5 ; \mathrm{NaH}_{2} \mathrm{PO}_{4}, 0.02 ; \mathrm{H}_{3} \mathrm{BO}_{3}, 0.01$; $\mathrm{MnCl}_{2} .4 \mathrm{H}_{2} \mathrm{O}, 1.8 ; \mathrm{Na}_{2} \mathrm{MoO}_{4}, 0.0001$; Cu-EDTA, 0.002; Fe-EDTA, 0.15; Mn-EDTA, 0.0006; Ni-EDTA, 0.0001 and Zn-EDTA, 0.012 (Koo, 2001). The micronutrient concentrations in sewage sludge were higher enough to support the development of plants (Table 1). The phytoavailability of some micronutrients originated from sewage sludge was evaluated. Micronutrients were not added in the nutrient solution to avoid phytotoxic effects and the addition of micronutrients in an inorganic form would difficult the conclusions.

Organic acids were collected twice (40 and 45 days after the planting). The procedure for the first collection was the same used by Koo (2001): the pots were disconnected from the hydroponics system and $2 \mathrm{~L}$ of bidistilled water was added, three times sequentially, to each pot, in order to clean residues from plant or microbial exudates, nutrients, and contaminants. Plants were left exposed to the sun by six hours to maximize the photosynthesis and exudation. Then, $2 \mathrm{~L}$ of deionized water was added to each pot and the leachates were collected and frozen.

The second collection (45 days after planting) differed from the first just in the amount of deionized water added before collecting the leachates, in the filtering and in the addition of chloroform to the leachate before freezing. Two hundred $\mathrm{mL}$ of deionized water were added and the leachate was collected after 10 minutes, filtered (Sterifil Aseptic, Millipore, Schleicher \& Schüll membrane, diameter, $47 \mathrm{~mm}$, and pores, $0,2 \mu \mathrm{m}$ ) and frozen.

Samples collected 40 days after planting were thawed, filtered and lyophilized. The material recovered from the lyophilizing process was solubilized in $1 \mathrm{~mL}$ of deionized water. The qualitative analysis of the organic acids was performed by a Dionex chromatograph equipped with an anionic exchange column IonPac ICE-AS 11. The presence of acetic, lactic and oxalic acids and just traces of butyric, citric, fumaric, gluconic, malic, succinic, and tartaric acids in the analyzed solutions, was detected.

Samples collected 45 days after planting were submitted to an organic acid quantitative analysis by high performance liquid chromatography (HPLC), equipped with a diode array detector and $\mathrm{C}_{18}$ column, reversed phase (Zorbax / SB); $\mathrm{H}_{2} \mathrm{PO}_{4} \mathrm{Na} 0,5 \mathrm{~mol} \mathrm{~L}^{-1}(\mathrm{pH} \mathrm{3,2}$ ), and $\mathrm{H}_{2} \mathrm{PO}_{4} 0,25 \% \mathrm{v} / \mathrm{v}(\mathrm{pH} 2,0)$ as mobile phase. Nitrate was removed from the samples by the Dowex 2 (Sigma Chemical CO.) anion exchange resin. The resin purification was as follows: the resin was hydrated with deionized water ( 24 hours); the supernatant was removed and the resin was shaken with $\mathrm{NaOH} 1 \mathrm{~mol} \mathrm{~L}^{-1}$ for 8 hours; the resin was washed five times with bidistilled water; the supernatant was removed and the resin was shaken in a $\mathrm{HCl} 1 \mathrm{~mol} \mathrm{~L}^{-1}$ solution for eight hours; the resin was washed with bidistilled water (five times). The proportion resin:solution for this purification was 1:5.

Dowex 2 is an anionic resin, so the organic acids present in a dissociated form in the solution could be retained. Due to the $\mathrm{pKa}$ of the analyzed organic acids (acetic, 4.76; citric, 3.14; 4.77, and 6.39; lactic, 3.08; oxalic, 1.23, and 4.19), if the $\mathrm{pH}$ of the samples in contact with the resin was approximately 1.00 , the organic acids in the solution were mainly present in their non-ionic form, not being retained. So, this separation was performed by adding $25 \mathrm{~mL}$ of purified resin a $100 \mathrm{~mL}$ sample. Then, a $2 \mathrm{~mol} \mathrm{~L}^{-1} \mathrm{HCl}$ solution was added until $\mathrm{pH}$ 1.0. The suspension was shaken for 8 hours, centrifuged (7,000 rpm) for 15 minutes and filtered. Nitrate-free samples were lyophilized for

Table 1. Sewage sludge chemical characteristics ${ }^{(1)}$.

\begin{tabular}{lclr}
\hline Characteristics & Concentration & Characteristics & Concentration \\
\hline Humidity $\left(\mathrm{g} \mathrm{kg}^{-1}\right)$ & 723.0 & Magnesium $\left(\mathrm{g} \mathrm{kg}^{-1}\right)$ & 4.3 \\
$\mathrm{pH}$ & 8.7 & Iron $\left(\mathrm{g} \mathrm{kg}^{-1}\right)$ & 32.0 \\
Organic C $\left(\mathrm{g} \mathrm{kg}^{-1}\right)$ & 373.5 & Aluminum $\left(\mathrm{g} \mathrm{kg}^{-1}\right)$ & 18.3 \\
$\mathrm{~N}-$ Kjeldahl $\left(\mathrm{g} \mathrm{kg}^{-1}\right)$ & 40.7 & Boron $\left(\mathrm{mg} \mathrm{kg}^{-1}\right)$ & 9.5 \\
Phosphorus $\left(\mathrm{g} \mathrm{kg}^{-1}\right)$ & 25.4 & Cadmium $\left(\mathrm{mg} \mathrm{kg}^{-1}\right)$ & 10.9 \\
Potassium $\left(\mathrm{g} \mathrm{kg}^{-1}\right)$ & 1.0 & Lead $\left(\mathrm{mg} \mathrm{kg}^{-1}\right)$ & 206.1 \\
Sodium $\left(\mathrm{g} \mathrm{kg}^{-1}\right)$ & 0.3 & Copper $\left(\mathrm{mg} \mathrm{kg}^{-1}\right)$ & 879.5 \\
Sulfur $\left(\mathrm{g} \mathrm{kg} \mathrm{g}^{-1}\right)$ & 13.6 & Chromium $\left(\mathrm{mg} \mathrm{kg}^{-1}\right)$ & 791.1 \\
Manganese $\left(\mathrm{mg} \mathrm{kg}^{-1}\right)$ & 266.2 & Nickel $\left(\mathrm{mg} \mathrm{kg}^{-1}\right)$ & 395.1 \\
Calcium $\left(\mathrm{g} \mathrm{kg}^{-1}\right)$ & 25.3 & Zinc $\left(\mathrm{mg} \mathrm{kg}^{-1}\right)$ & $2,827.3$ \\
\hline
\end{tabular}

${ }^{(1)}$ Concentration values in dry mass basis. 
72 hours. The remaining material was solubilized in $10 \mathrm{~mL}$ deionized water and filtered (qualitative filter paper) to avoid microbial degradation.

Shoots were harvested after the second organic acids collection (45 days after planting). Shoots were washed in tap water, followed by $0.1 \mathrm{~mol} \mathrm{~L}^{-1} \mathrm{HCl}$ solution, and deionized water. Washed shoots were dried at $65^{\circ} \mathrm{C}$ for five days, and weighted for biomass. For metal determination, aliquots of $0.5 \mathrm{~g}$ plant tissues were digested by a mixture of $4.0 \mathrm{~mL}$ concentrated $\mathrm{HNO}_{3}+$ $4.0 \mathrm{~mL} \mathrm{H}_{2} \mathrm{O}_{2}+2.0 \mathrm{~mL} \mathrm{H}_{2} \mathrm{O}$, in a $120 \mathrm{~mL}$ in Teflon Parr bombs (HP-500) on a microwave assisted digestion procedure based on temperature (Sah and Miller, 1992). Analyses of $\mathrm{Cd}, \mathrm{Cr}, \mathrm{Cu}, \mathrm{Pb}, \mathrm{Ni}$, and $\mathrm{Zn}$ in the digested material were performed by inductive coupled plasma (ICP-AES).

Results were submitted to variance analysis (ANOVA - F test 5\%) and averages obtained in each treatment, not only for trace element concentrations in shoots, but also for organic acid concentrations in the rhizosphere, were compared by Tukey test, at five percent of probability. Linear correlation analysis was applied to verify an association of organic acid and trace element concentrations.

\section{Results and Discussion}

Dried biomass produced by the majority of the analyzed plants in the control treatments was similar to the sewage sludge treatments due to the constant nutrient supply in all treatments. On the other hand, dried root weight for the control treatment was smaller than for the sewage sludge treatments, except for eucalyptus (Figure 1). Sewage sludge treatments, possibly, presented better water retention, substrate aggregation, and greater microbial activity, among other beneficial factors. It is also important to mention that all the treatments presented roots filling the total volume of the vase, which is the condition to collect representative samples of the rhizosphere. Even eucalyptus treatments (control and sewage sludge), whose plants presented, visually, the same size of shoots when planted and when harvested, attended to this condition.

Variance analysis showed that the factors of variability presence/absence of sewage sludge, plant species and their interaction were significative (F test $5 \%$ ) for all metals analyzed, except for lead, whose concentrations were below the equipment detection limits $\left(0.01 \mathrm{mg} \mathrm{L}^{-1}\right)$.

For the control treatments, chromium and nickel concentrations were similar regardless of the plant species (Table 2), as cadmium, copper, and zinc concentrations differ depending on it. Sugar cane plants presented the smallest concentration of $\mathrm{Cu}$ in the shoots while eucalyptus plants presented the highest concentration of $\mathrm{Zn}$.

For sewage sludge treatments, the majority of plant species presented higher concentrations of trace elements in the shoots when compared to the control treatments, except for sugarcane with $\mathrm{Cd}, \mathrm{Cr}, \mathrm{Cu}$ and $\mathrm{Ni}$ and marandu grass with $\mathrm{Cu}$. This result evidences that part of the trace elements originated from sewage sludge was phytoavailable and/or phytoavailability processes occurred under the sewage sludge treatment, since the residue was the only source of these elements
Shoot

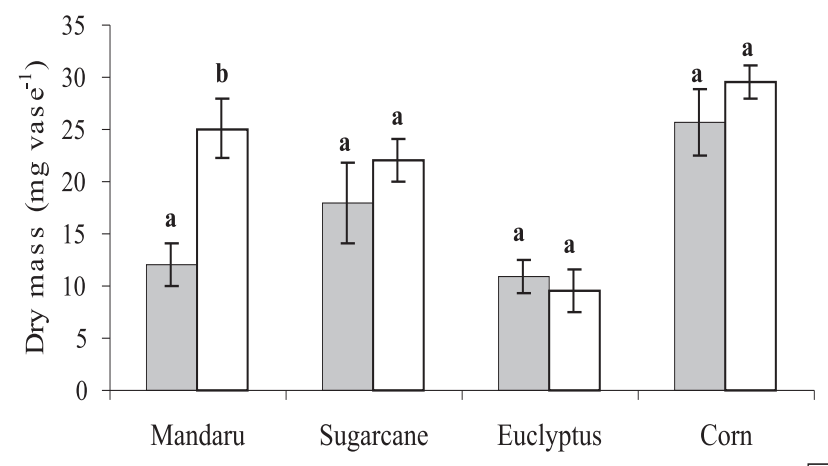

Root

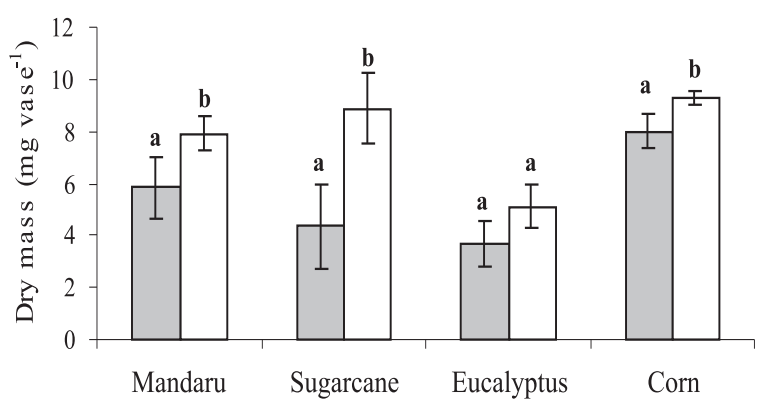

$\square$ Control $\square \mathrm{SS}$

Figure 1. Dry mass produced by the shoots and roots from different plant species cultivated in sand (Control) or in sewage sludge-treated sand (SS). Treatments with the same letter for each species are similar (Tukey, 5\%). 
for plants. Sugar cane presented the lowest trace element concentrations in the shoots. Silva (1995) analyzed $\mathrm{Cd}, \mathrm{Cr}, \mathrm{Ni}$, and $\mathrm{Pb}$ in the sugarcane shoots grown in sewage sludge-treated soils (up to $40 \mathrm{Mg} \mathrm{kg}^{-1}$ ) and detected only trace concentrations of those elements. Oliveira \& Mattiazzo (2001) evaluated for two years trace elements uptake by sugarcane grown in a sewage sludgetreated Oxisol (90 and $110 \mathrm{Mg} \mathrm{ha}^{-1}$, dry weight basis), and only observed the presence of $\mathrm{Cu}$ and $\mathrm{Zn}$ in leaves, as the foliar concentration for $\mathrm{Cd}, \mathrm{Cr}, \mathrm{Ni}$, and $\mathrm{Pb}$ was below the detection limit.

Among the studied plant species, eucalyptus grown in sewage sludge-treated sand presented the highest concentrations of $\mathrm{Cd}, \mathrm{Cr}, \mathrm{Cu}, \mathrm{Ni}$, and $\mathrm{Zn}$ in the shoots, followed by marandu grass. Andrade et al. (2000) evaluated the uptake of these elements by one year old eucalyptus, grown in a sewage sludge-treated Oxisol $\left(0,10,20\right.$, and $40 \mathrm{Mg}$ biosolid ha ${ }^{-1}$, dry weight basis) and reported that cadmium and chromium were not detected in the collected leaves; the increase in sewage sludge doses did not result in an increase of $\mathrm{Cu}, \mathrm{Ni}$, and $\mathrm{Zn}$ uptake by plants, suggesting that, under the experimental conditions, trace elements were not available for eucalyptus. Their result could be referred to the fact that, in their experiment, sewage sludge was applied to soil surface, without incorporation.

Copper concentrations found in the studied plants were situated beyond the interval normally observed on the dry masses of different plant species, pointed out by Baker (1990). Dechen et al. (1991) commented that Zn concentration in plant tissues depends on the plant species and soil type. Frequently $\mathrm{Zn}$ concentrations in plants vary from 20 to $50 \mathrm{mg} \mathrm{kg}^{-1}$, and the deficiency symptoms are common when the concentration is below $20 \mathrm{mg} \mathrm{kg}^{-1}$. Kiekens (1990) classifies the concentration of $\mathrm{Zn}$ in the dry mass of plants as: deficient $(<10-20)$; adequate $(<25-150)$; and toxic $\left(>400 \mathrm{mg} \mathrm{kg}^{-1}\right)$. Following the above classification, $\mathrm{Zn}$ concentrations in plant shoots are considered non-toxic for plants. Symptoms of nutrient deficiency or toxicity were not observed in the plants in the present experiment.

The qualitative organic acid analysis in the leachates from the first collection revealed the presence of acetic, lactic and oxalic acids and trace concentrations of butyric, citric, fumaric, gluconic, malic, succinic, and tartaric acids.

Although citric acid was found by some authors ( $\mathrm{Li}$ et al., 1997; Gardner et al., 1983) as the most abundant in the rhizosphere, significative concentrations of this acid in the quantitative analysis were not detected. Citric acid is rapidly degraded in the soil or converted into other metabolites (Jones et al., 1996). So, in the second collection, the filtering and chloroform addition to the leachate samples were performed before lyophilizing the samples to reduce citric acid losses, avoiding its degradation. These changes in the procedure, from the first to the second organic acids collection, were effective since only trace concentrations of citric acid were detected in the first collection, but it was quantified successfully in the leachates of the second one. Plant species presented similar organic acids composition in their rhizospheres (Figure 2).

For sewage sludge treatments, the organic acids composition was similar, even when different species were considered. The average percentages for each acid were $43.21,31.13,20.41$, and 5.25 for acetic, citric, lactic, and oxalic acids, respectively. Koo (2001) also found similarities on the organic acid composition for different plant species - corn, durum wheat, rape, sudan grass, chickpea, and swiss chard -, and the acetic, lactic, butyric, and oxalic acids were responsible for 72 to $88 \%$ of the total organic acids collected. Cieslinski et al. (1998) evaluated the organic acids composition in the wheat rhizosphere in three different soils, oxalic, fumaric, succinic, malic,

Table 2. Trace element concentrations in the shoot of marandu grass, sugarcane, eucalyptus, and corn cultivated in sand (control) or in sewage sludge-treated sand $(\mathrm{SS})^{(1)}$.

\begin{tabular}{|c|c|c|c|c|c|c|c|c|c|c|}
\hline \multirow[t]{2}{*}{ Plant species } & \multicolumn{2}{|c|}{$\mathrm{Cd}$} & \multicolumn{2}{|c|}{$\mathrm{Cr}$} & \multicolumn{2}{|c|}{$\mathrm{Cu}$} & \multicolumn{2}{|c|}{$\mathrm{Ni}$} & \multicolumn{2}{|r|}{$\mathrm{Zn}$} \\
\hline & Control & SS & Control & SS & Control & SS & Control & SS & Control & SS \\
\hline Marandu & $0.12 \mathrm{Aab}(0.04)$ & $0.46 \mathrm{Bab}(0.09)$ & $0.10 \mathrm{Aa}(0.02)$ & $0.22 \mathrm{Bb}(0.08)$ & $7.60 \mathrm{Aa}(2.20)$ & $\begin{array}{l}\left.\mathrm{g} \mathrm{kg}^{-1}\right)- \\
11.00 \mathrm{Bb}(0.88)\end{array}$ & $0.29 \mathrm{Aa}(0.04)$ & $3.68 \mathrm{Bc}(0.44)$ & $23.72 \mathrm{Ab}(2.15)$ & $130.46 \mathrm{Bb}(6.14)$ \\
\hline Sugarcane & $0.07 \mathrm{Ab}(0.02)$ & $0.15 \mathrm{Ac}(0.02)$ & $0.00 \mathrm{Aa}(0.00)$ & $0.08 \mathrm{Ac}(0.03)$ & $1.63 \mathrm{Ab}(0.31)$ & $2.85 \mathrm{Ac}(0.26)$ & $0.10 \mathrm{Aa}(0.06)$ & $0.52 \mathrm{Ad}(0.07)$ & $11.75 \mathrm{Ab}(1.81)$ & $22.17 \mathrm{Bd}(2.37)$ \\
\hline Eucalyptus & $0.26 \mathrm{Aa}(0.08)$ & $0.59 \mathrm{Ba}(0.19)$ & $0.11 \mathrm{Aa}(0.01)$ & $0.28 \mathrm{Bab}(0.03)$ & $10.97 \mathrm{Aa}(0.71)$ & $23.88 \mathrm{Ba}(5.98)$ & $0.97 \mathrm{Aa}(0.37)$ & $6.59 \mathrm{Ba}(0.93)$ & 45.07Aa (3.58) & $153.95 \mathrm{Ba}(12.43)$ \\
\hline Corn & $0.11 \mathrm{Aab}(0.02)$ & $0.35 \mathrm{Bb}(0.12)$ & $0.01 \mathrm{Aa}(0.00)$ & $0.41 \mathrm{Ba}(0.17)$ & $7.43 \mathrm{Aa}(1.57)$ & $11.18 \mathrm{Ab}(2.99)$ & $0.01 \mathrm{Aa}(0.01)$ & $5.34 \mathrm{Bb}(0.87)$ & $16.83 \mathrm{Ab}(1.79)$ & $97.94 \mathrm{Bc}(9.12)$ \\
\hline
\end{tabular}

${ }^{(1)}$ Treatments with the same letter (lower case) in the same column are similar (Tukey, 5\%); treatments (control and sewage sludge) with the same letter (upper case) in the same line for each trace element are similar (Tukey, 5\%); Control: sand; SS: sewage sludge-treated sand; standard deviation between parentheses. 
tartaric, citric, acetic, propionic, and butyric acids were identified, but acetic and succinic acids were found in greater concentrations.

For most of the plant species, sewage sludge treatments presented better root system development (Figure 1). The rhizosphere of a more developed root system is expected to produce more root exudates and to present greater microbial activity, which results in an increase of organic acid concentrations (Mench et al., 1988; Uren \& Reisenauer, 1988; Laurie \& Manthey, 1994). The results were in agreement with these premises since the organic acid concentrations produced in the sewage sludge treatments were higher than in the control treatments for all plant species, except for the acetic, citric, and total acids concentration in the treatments without plants (Table 3). For lactic and oxalic acids, the interaction between the variance factors presence/absence of sewage sludge and plant species was not significative (F test 5\%). Regarding the variance factor presence/absence of sewage sludge, concentrations of lactic and oxalic acids (mmol kg-1 soil) in control samples (C) were

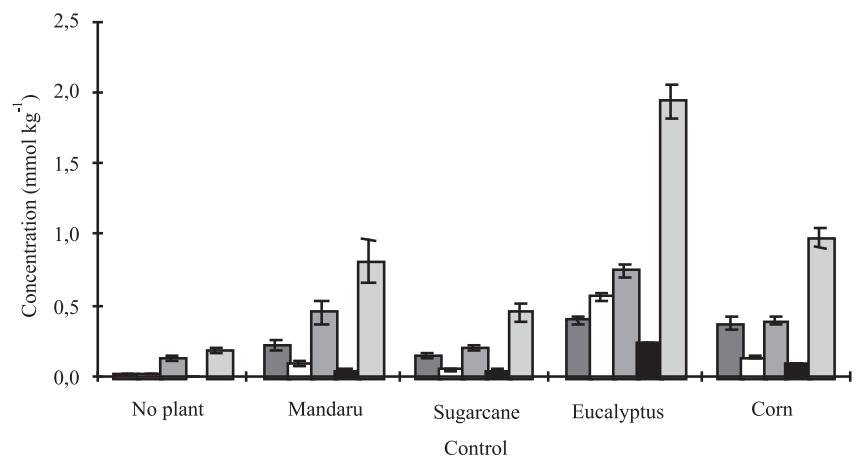

$\square$ Acetic $\square$ Citric $\square$ Lactic $\square$ Oxalic $\square$ Total lower to those found in sewage sludge treatments (SS): lactic, 0.47 (SS) and 0.39 (C), and oxalic, 0.12 (SS) and $0.08(\mathrm{C})$.

For the sewage sludge treatments, the organic acid concentrations present on the rhizosphere varied depending on the plant species. Sugar cane presented the smallest concentration of organic acids in the rhizosphere and it was similar, in general, to the treatments without plants. Organic acid production was higher in eucalyptus, followed by corn and marandu grass. The majority of available scientific data about organic acids in the rhizosphere show isolated results for one plant species, complicating the comparison between them, as the experimental conditions are not standard.

The concentration of all organic acids, individually, correlated positively to the concentration of trace elements in plants, except for citric acid with all elements, and lactic and oxalic acids with $\mathrm{Cr}$ (Table 4). Mench \& Martin (1991) found similar results and concluded that citric acid is not suitable to be used to extract phytoavailable trace elements present in sewage sludge treated soils grown with corn.

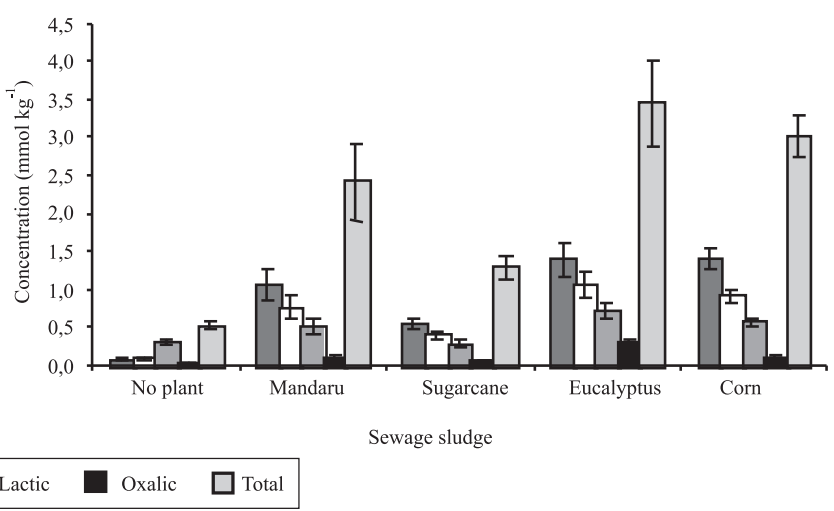

Figure 2. Organic acids composition in the rhizosphere (mmol organic acids $\mathrm{kg}^{-1}$ soil) of different plant species cultivated in sand (Control) or in sewage sludge-treated sand $(\mathrm{SS})^{(1)}$.

Table 3. Concentration of acetic, citric, lactic and oxalic acids collected from the rhizosphere of different species cultivated in sand (Control) or in sewage sludge-treated sand (SS) ${ }^{(1)}$.

\begin{tabular}{|c|c|c|c|c|c|c|c|c|}
\hline \multirow[t]{2}{*}{ Plant species } & \multicolumn{2}{|c|}{ Acetic } & \multicolumn{2}{|c|}{ Citric } & \multirow[t]{2}{*}{$\operatorname{Lactic}^{(2)}$} & \multirow[t]{2}{*}{ Oxalic $^{(2)}$} & \multicolumn{2}{|c|}{ Total } \\
\hline & Control & SS & Control & SS & & & Control & SS \\
\hline & & & & & $\left.\mathrm{kg}^{-1}\right)$-------- & & & \\
\hline $\begin{array}{l}\text { No plant } \\
\text { Marandu }\end{array}$ & $\begin{array}{l}0.02 \mathrm{Ab}(0.00) \\
0.22 \mathrm{Aab}(0.05)\end{array}$ & $\begin{array}{l}0.08 \mathrm{Ad}(0.01) \\
1.06 \mathrm{Bb}(0.28)\end{array}$ & $\begin{array}{l}0.02 \mathrm{Ab}(0.00) \\
0.09 \mathrm{Ab}(0.02)\end{array}$ & $\begin{array}{l}0.09 \mathrm{Ad}(0.01) \\
0.76 \mathrm{Bb}(0.19)\end{array}$ & $\begin{array}{l}0.22 \mathrm{c}(0.10) \\
0.48 \mathrm{~b}(0.11)\end{array}$ & $\begin{array}{l}0.02 \mathrm{~d}(0.02) \\
0.07 \mathrm{bc}(0.04)\end{array}$ & $\begin{array}{l}0.18 \mathrm{Ab}(0.03) \\
0.81 \mathrm{Ab}(0.18)\end{array}$ & $\begin{array}{l}0.52 \mathrm{Ac}(0.06) \\
2.42 \mathrm{Bb}(0.62)\end{array}$ \\
\hline Sugarcane & $0.15 \mathrm{Aab}(0.03)$ & $0.54 \mathrm{Bc}(0.08)$ & $0.05 \mathrm{Ab}(0.01)$ & $0.45 \mathrm{Bc}(0.06)$ & $0.24 \mathrm{c}(0.06)$ & $0.05 \mathrm{~cd}(0.01)$ & $0.45 \mathrm{Ab}(0.07)$ & $1.29 \mathrm{Bc}(0.20)$ \\
\hline Eucalyptus & $0.40 \mathrm{Aa}(0.03)$ & $1.39 \mathrm{Bab}(0.27)$ & $0.56 \mathrm{Aa}(0.04)$ & $1.05 \mathrm{Ba}(0.22)$ & $0.73 \mathrm{a}(0.10)$ & $0.26 \mathrm{a} 0.05)$ & $1.93 \mathrm{Aa}(0.13)$ & $3.44 \mathrm{Ba}(0.70)$ \\
\hline Corn & $0.37 \mathrm{Aa}(0.04)$ & $1.40 \mathrm{Ba}(0.15)$ & $0.13 \mathrm{Ab}(0.01)$ & $0.92 \mathrm{Bab}(0.10)$ & $0.48 \mathrm{~b}(0.21)$ & $0.10 \mathrm{~b}(0.02)$ & $0.98 \mathrm{Ab}(0.09)$ & $3.01 \mathrm{Bab}(0.33)$ \\
\hline
\end{tabular}

${ }^{(1)}$ Treatments with the same letter (lower case) in the same column are similar (Tukey, 5\%); treatments (control and sewage sludge) with the same letter (upper case) in the same line for each trace element are similar (Tukey, 5\%); Control: sand; SS: sewage sludge-treated sand; standard deviation between parentheses. ${ }^{(2)}$ Interaction between the factors presence of sewage sludge and plant species were not significative $(5 \%)$. 
Table 4. Correlation coefficients for linear adjustment between the concentration of trace elements in the shoots and the concentration of organic acids in the rhizosphere of marandu, sugarcane, eucalyptus, and corn cultivated in sand or in sewage sludge-treated sand.

\begin{tabular}{cccccc}
\hline Trace element & Acetic & Citric & Lactic & Oxalic & Total $^{(1)}$ \\
\hline $\mathrm{Cd}$ & $0.60^{*}$ & $\mathrm{~ns}$ & $0.35^{*}$ & $0.42^{*}$ & $0.66^{*}$ \\
$\mathrm{Cr}$ & $0.65^{*}$ & ns & ns & ns & $0.59^{*}$ \\
$\mathrm{Cu}$ & $0.46^{*}$ & ns & $0.57^{*}$ & $0.68^{*}$ & $0.61^{*}$ \\
$\mathrm{Ni}$ & $0.85^{*}$ & ns & $0.31^{*}$ & $0.36^{*}$ & $0.80^{*}$ \\
$\mathrm{Zn}$ & $0.79^{*}$ & ns & $0.36^{*}$ & $0.41^{*}$ & $0.80^{*}$ \\
\hline
\end{tabular}

${ }^{(1)}$ Result of the sum of the quantities of acetic, citric, lactic, and oxalic

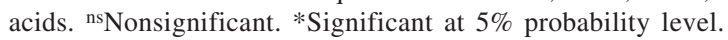

The sum of the quantities of the concentrations of acetic, citric, lactic, and oxalic acids correlated with $\mathrm{Cd}, \mathrm{Cr}, \mathrm{Cu}$, $\mathrm{Ni}$, and $\mathrm{Zn}$ concentrations found in the shoots of the studied plants. This result indicates that organic acids from the rhizosphere could be directly involved with the trace elements phytoavailability in sewage sludge treated soils.

\section{Conclusions}

1. Acetic, citric, lactic, and oxalic are the main acids found in the rhizosphere of different species cultivated in the presence of sewage sludge.

2. There is a positive relationship between the presence of organic acids of low molecular weight in the rhizosphere and sewage sludge-borne trace-elements phytoavailability.

\section{Acknowledgement}

To Fapesp, for the financial support.

\section{References}

ANDRADE, C.A.; MATTIAZZO, M.E. Nitratos e metais pesados no solo e nas árvores após a aplicação de biossólido (lodo de esgoto) em plantações florestais de Eucaliptus grandis. Scientia Forestalis, v.58, p.59-72, 2000.

BAKER, D.E. Copper. In: ALLOWAY, B.J. (Ed.). Heavy metals in soils. Glasgow: Blackie A\&P, 1990. p.152-176.

BERTONCINI, E.I. Comportamento de Cd, $\mathrm{Cr}$, $\mathrm{Cu}$, Ni e $\mathrm{Zn}$ em latossolos sucessivamente tratados com biossólido: extração sequencial, fitodisponibilidade e caracterização de substâncias húmicas. 2002. 195p. Tese (Dotutorado) - Universidade de São Paulo, Piracicaba.

CANDELARIA, L.M. Ion activities, solution speciation and solid phase distribution of metals in sludge-amended soils with an emphasis on cadmium. 1995. 136p. Thesis (Ph.D.) - University of California, Riverside.
CETESB - COMPANHIA DE TECNOLOGIA DE SANEAMENTO AMBIENTAL. Aplicação de biossólido em áreas agrícolas: critérios para projeto e operação. São Paulo: [s.n.] 1999. 35p. (Manual técnico).

CHANG, A.C.; HYUN, H.; PAGE, A.L. Cadmium uptake for swiss chard grown on composted sludge treated field plots: Plateau or time bomb? Journal of Environmental Quality, v.26, p.11-19, 1997.

CHEN, Y.X.; LIN, Q.; LUO, Y.M.; HE, Y.F.; ZHEN, S.J.; YU, Y.L.; TIAN, G.M.; WONG, M.H. The role of citric acid on the phytoremediation of heavy metal contaminated soil. Chemosphere, v.50, p.807-811, 2003.

CIESLINSKI, G.; REES, K.C.J. van; SZMIGIELSKA, A.M.; KRISHNAMURTI, G.S.R.; HUANG, P.M. Low-molecular-weight organic acids in rhizosphere soils of durum wheat and their effect on cadmium bioaccumulation. Plant and Soil, v.203, p.109-117, 1998.

DECHEN, A.R.; HAAG, H.P.; CARMELLO, Q.A. de C. Micronutrientes na planta. In: FERREIRA, M.E.; CRUZ, M.C.P. (Ed.). Micronutrientes na agricultura. Piracicaba: Potafos, 1991. p.65-75.

EATON, A.D.; CLESCERI, L.S.; GREENBERG, A.C. Standards methods for the examination of water and wastewater. 19.ed. Washington: American Public Health Association, 1995. 1082p.

ESTADOS UNIDOS. Environmental Protection Agency. 40 CFRPart 503 final rules: standards for the use of sewage sludge. Washington, 1993. p.9387-9415. (Federal Register, 58).

GARDNER, W.K.; BARBER, D.A.; PARBERY, D.G. The acquisition of phosphorus by Lupinus albus L. III. The probable mechanism by which phosphorus movement in the soil/root interfaces is enhanced. Plant and Soil, v.70, p.107-124, 1983.

JONES, D.L.; DARRAH, P.R.; KOCHIAN, L.V. Critical evaluation of organic acid mediated iron dissolution in the rhizosphere and its potential role in root ion uptake. Plant and Soil, v.182, p.221-228, 1996.

KIEKENS, L. Zinc. In: ALLOWAY, B.J. (Ed.). Heavy Metals in Soils. Glasgow: Blackie A\&P, 1990. p.261-279.

KOO, B.J. Assessing bioavailability of metals in biosolid treated soils: root exudates and their effects on solubility of metals. 2001. 261p. Thesis (Ph.D.) - University of California, Riverside.

KRISHNAMURTI, G.S.R.; CIESLINSKI, G.; HUANG, P.M.; REES, K.C.J. van Kinetics of cadmium release from soils as influenced by organic acids: implication in cadmium availability. Journal of Environmental Quality, v.26, p.271-277, 1997.

LAUHEURTE, F.; LEYVAL, C.; BERTHELIN, J. Root exudates of maize, pine and beech seedlings influenced by mycorrhizal and bacterial inoculation. Simbiosis, v.9, p.111-116, 1990.

LAURIE S.H.; MANTHEY, J.A. The chemistry and role of metal ion chelation in plant uptake processes. In: MANTHEY, J.A.; CROWLEY, D.E.; LUSTER, D.G. (Ed.). Biochemistry of metal micronutrients in the rhizosphere. Boca Raton: Lewis Publishers, 1994.

LI, M.G.; SHINANO, T.; TADANO, T. Distribution of exudates of lupin rotos in the rhizosphere under phosphorus deficient conditions. Soil Science and Plant Nutrition, v.43, p.237-245, 1997. 
MARSCHNER, H. Mineral nutrition of higher plants. London: Academic Press, 1995. 889p.

McBRIDE, M.B. Toxic metal accumulation from agricultural use of sludge: are USEPA regulations protective? Journal of Environmental Quality, v.24, p.5-18, 1995.

MENCH, M.; MARTIN, M. Mobilization of cadmium and other metals from two soils by root exudates of Zea mays L., Nicotiana tobaccum L., and Nicotiana rustica L. Plant and Soil, v.132, p.187-196, 1991.

MENCH, M.; MOREL, J.L.; GUCKERT, A.; GUILLET, B. Metal binding with root exudates of low molecular weight. Journal of Soil Science, v.39, p.521-527, 1988.

NATIONAL RESEARCH COUNCIL. Risk assessment and management: framework for decision making. Washington: National Academy of Science Press, 1983. 1543p.
OLIVEIRA, F.C.; MATTIAZZO, M.E. Metais pesados em Latossolo tratado com lodo de esgoto e em plantas de cana de açúcar. Scientia Agricola, v.58, p.581-593, 2001.

QIN, F.; SHAN, X.; WEI, B. Effects of low-molecular-weight organic acids and residence time on desorption of $\mathrm{Cu}, \mathrm{Cd}$ and $\mathrm{Pb}$ from soils. Chemosphere, v.57, p.253-263, 2004.

SAH, R.N.; MILLER, R.O. Spontaneous reaction for acid dissolution of biological tissues in closed vessels. Analytical Chemistry, v.64, p.102-103, 1992.

SILVA, F.C. Uso agronômico de lodo de esgoto: efeitos em fertilidade do solo e qualidade da cana-de-açúcar. 1995. 170p. Tese (Doutorado) - Universidade de São Paulo, Piracicaba.

SPOSITO, G. Trace metals in contaminated waters. Environmental Science and Technology, v.15, p.396-403, 1981.

UREN, N.C.; REISENAUER, H.M. The role of root exudates in nutrient acquisition. Advances in Plant Nutrition, v.3, p.79-114, 1988.

Received on December 11, 2006 and accepted on June 18, 2007 